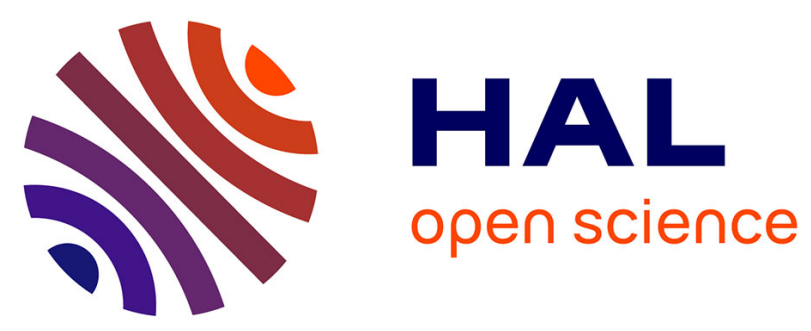

\title{
New biobased-zwitterionic ionic liquids: efficiency and biocompatibility for the development of sustainable biorefinery processes
}

Gael Huet, Monica Araya-Farias, Ranim Alayoubi, Sylvain Laclef, Benjamin Bouvier, Isabelle Gosselin, Christine Cézard, Romain Roulard, Matthieu Courty, Caroline Hadad, et al.

\section{To cite this version:}

Gael Huet, Monica Araya-Farias, Ranim Alayoubi, Sylvain Laclef, Benjamin Bouvier, et al.. New biobased-zwitterionic ionic liquids: efficiency and biocompatibility for the development of sustainable biorefinery processes. Green Chemistry, 2020, 22 (9), pp.2935-2946. 10.1039/D0GC01002B . hal02571443

\section{HAL Id: hal-02571443 \\ https://hal.science/hal-02571443}

Submitted on 12 May 2020

HAL is a multi-disciplinary open access archive for the deposit and dissemination of scientific research documents, whether they are published or not. The documents may come from teaching and research institutions in France or abroad, or from public or private research centers.
L'archive ouverte pluridisciplinaire HAL, est destinée au dépôt et à la diffusion de documents scientifiques de niveau recherche, publiés ou non, émanant des établissements d'enseignement et de recherche français ou étrangers, des laboratoires publics ou privés. 


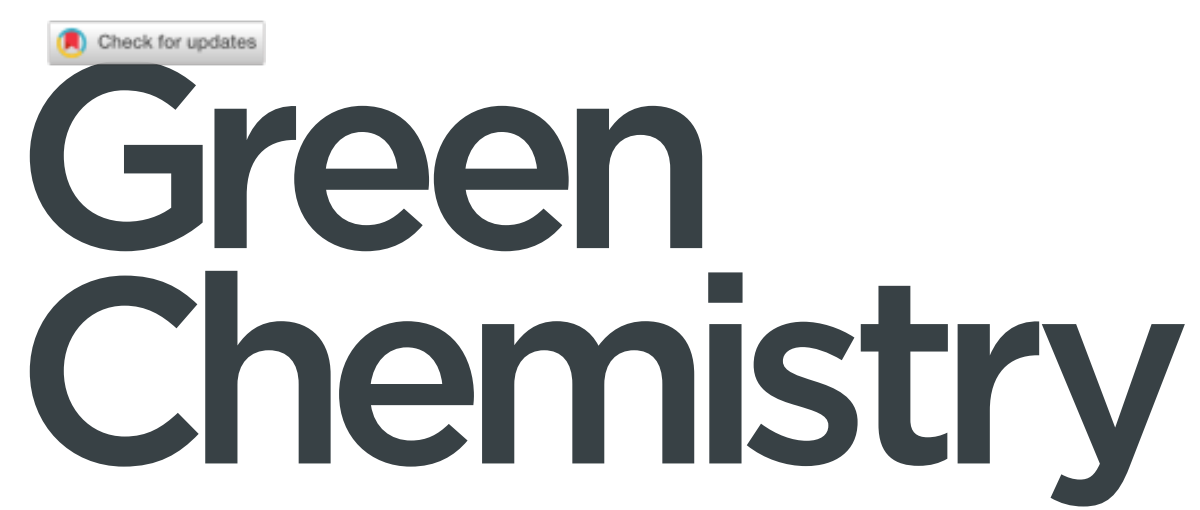

Cutting-edge research for a greener sustainable future

\section{Accepted Manuscript}

This article can be cited before page numbers have been issued, to do this please use: G. huet, M. arayafarias, R. alayoubi, S. LACLEF, B. Bouvier, I. Gosselin, C. Cezard, R. roulard, M. Courty, C. hadad, E. Husson,

C. Sarazin and A. NguyenVan Nhien, Green Chem., 2020, DOI: 10.1039/D0GC01002B.

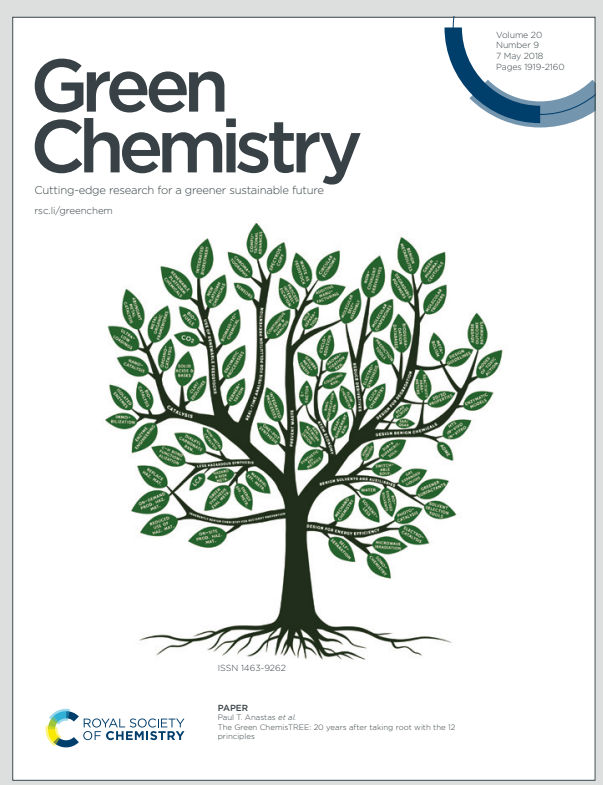

This is an Accepted Manuscript, which has been through the Royal Society of Chemistry peer review process and has been accepted for publication.

Accepted Manuscripts are published online shortly after acceptance, before technical editing, formatting and proof reading. Using this free service, authors can make their results available to the community, in citable form, before we publish the edited article. We will replace this Accepted Manuscript with the edited and formatted Advance Article as soon as it is available.

You can find more information about Accepted Manuscripts in the Information for Authors.

Please note that technical editing may introduce minor changes to the text and/or graphics, which may alter content. The journal's standard Terms \& Conditions and the Ethical guidelines still apply. In no event shall the Royal Society of Chemistry be held responsible for any errors or omissions in this Accepted Manuscript or any consequences arising from the use of any information it contains. 


\title{
ARTICLE
}

\section{New Biobased-Zwitterionic lonic Liquids: Efficiency and Biocompatibility for the Development of Sustainable Biorefinery \\ Processes}

Received 00th January 20xx, Accepted 00th January 20xx DOI: $10.1039 / x 0 x \times 00000 x$

Gaël Huet, ${ }^{a}$ Monica Araya-Farias, ${ }^{\text {b,c }}$ Ranim Alayoubi, ${ }^{b}$ Sylvain Laclef, ${ }^{a}$ Benjamin Bouvier, ${ }^{\text {a }}$ Isabelle Gosselin, ${ }^{\mathrm{b}}$ Christine Cézard, ${ }^{\mathrm{a}}$ Romain Roulard, ${ }^{\mathrm{d}}$ Matthieu Courty, ${ }^{\mathrm{e}}$ Caroline Hadad, ${ }^{\mathrm{a}}$ Eric Husson, ${ }^{\mathrm{b}}$ Catherine Sarazin, ${ }^{\mathrm{b}}$ Albert Nguyen Van Nhien*a

\begin{abstract}
A new family of biobased-Zwitterionic lonic Liquids (ZILs) have been synthetized starting from the renewable resource Lhistidine natural amino acid and varying the length of the alkyl chains. These ZILs derivatives were firstly studied for their biocompatibility with different microorganisms including bacteria, molds and yeast. The obtained MIC values indicated that all the microorganisms were 5 to 25 times more tolerant to ZIL derivatives than the robust 1-ethyl-3methylimidazolium acetate $\left[\mathrm{C}_{2} \mathrm{mim}\right][\mathrm{OAc}]$ used as a reference. Modeling studies also revealed that the presence of the cation and the anion on the same skeleton together with the length of the $N$-alkyl chain would govern the biocompatibility of these neoteric solvents. Among the different synthesized ZILs, the $N, N^{\prime}$-diethyl derivative has demonstrated to be a suitable eco-alternative to the classically used $\left[\mathrm{C}_{2} \mathrm{mim}\right][\mathrm{OAc}]$ for efficient pretreatment of harwood sawdust leading to significative improvement of enzymatic saccharrification. In addition, up to $5 \% \mathrm{w} / \mathrm{v}$ concentration in the media culture, ZIL did not induce deleterious effect on fermentative yeast growth nor ethanol production.
\end{abstract}

\section{Introduction}

lonic Liquids (ILs) are generally defined as organic salts based on a substituted heterocyclic cation with an organic or inorganic anion that melt below $100{ }^{\circ} \mathrm{C}$. In addition to their thermal stability and low vapour pressure, some of them can be considered as suitable solvent to solubilize the constitutive biopolymers of lignocellulosic biomass (LCB). The ILpretreatment of LCB demonstrated a great potential for improving the availability of the constitutive polymers and thus their respective conversion into platform molecules, high added value chemicals or biofuels..$^{1-3}$ By this way, hydrophilic imidazolium-based ILs as 1-ethyl-3-methylimidazolium acetate $\left[\mathrm{C}_{2} \mathrm{mim}\right][\mathrm{OAc}]$ recently emerged in the biorefinery area as an

a. Laboratoire de Glycochimie, des Antimicrobiens et des Agroressources, UMR CNRS 7378, Université de Picardie Jules Verne - UFR des Sciences, 33 rue Saint Leu, 80039 Amiens cedex, France.

E-mail: albert.nguyen-van-nhien@u-picardie.fr

b. Unité de Génie Enzymatique et Cellulaire, UMR CNRS 7025, Université de Picardie Jules Verne - UFR des Sciences, 33 rue Saint Leu, 80039 Amiens Cedex, France. Macromolecules and Microsystems in Biology and Medecine, Institut Curie Centre de Recherche - UMR 168 Physico Chimie Curie, Institut Pierre Gilles de Gennes pour la Microfluidique (IPGG), 6, rue Jean Calvin, 75005 Paris, France.

d. Plateforme de Microscopie Electronique - Université de Picardie Jules Verne, HUB de l'Energie, 33 rue Saint Leu, 80039 Amiens Cedex, France.

e. Laboratoire de Réactivité et Chimie des Solides, UMR CNRS 7314, Université de Picardie Jules Verne, HUB de l'Energie, 33 rue Saint Leu, 80039 Amiens Cedex, France.

Electronic Supplementary Information (ESI) available: [details of any supplementary information available should be included here]. See DOI: $10.1039 / x 0 x x 00000 x$ efficient alternative to other pretreatments prior to LCB transformation. ${ }^{4-8}$ Although their ability to disrupt or fractionate LCB in mild conditions is admitted, their scale-up at industrial scale is still constrained by a questionable safety context due to their eco-cytotoxicity ${ }^{9}$ and limited compatibility with the biological tools (enzymes, cells) used in the biorefinery processes. Moreover, the imidazolium-based ILs are mainly synthesized from non-renewable feedstock. They can also affect performances of both enzymatic hydrolysis and microbial fermentation steps during LCB bioconversion processes. Indeed, residual $\left[\mathrm{C}_{2} \mathrm{mim}\right][\mathrm{OAc}]$ amount entrapped in pretreated LCB can induce deactivation of hemicellulolytic enzymes during hydrolysis step. ${ }^{10}$ Similarly, inhibition of yeast growth was observed from [ $\left.\mathrm{C}_{2} \mathrm{mim}\right][\mathrm{OAc}]$ concentration of 0.5 $\%(w / w)$ during fermentation step. ${ }^{11-13}$

To minimize these deleterious effects, successive washing of pretreated LCB requiring a large amount of water can be implemented after pretreatment step, but remained quite often insufficient.

More recently, Kuroda et al. ${ }^{14}$ demonstrated that ZILs could be an interesting alternative to ILs, particularly for LCB pretreatment prior enzymatic saccharification followed by microbial production of ethanol. Nevertheless, those derivatives are not synthesized from renewable resources. Until now, few imidazolium-ZIL derivatives have been synthesized and characterized. ${ }^{15,16}$ The studies were mainly conducted in the area of (organo)catalysis. ${ }^{17,} 18$ The few examples described only their ability to dissolve ${ }^{19}$ or to hydrolyse cellulose. ${ }^{20} \mathrm{~A}$ strategy including pretreatment of LCB 
with $\mathrm{H}_{2} \mathrm{SO}_{4}$, addition of $\left[\left(\mathrm{SO}_{3}\right)^{4} \mathrm{C}_{4} \mathrm{C}_{1}\right.$ im] zwitterion for in situ synthesis of $\left[\left(\mathrm{HSO}_{3}\right)^{4} \mathrm{C}_{4} \mathrm{C}_{1} \mathrm{im}\right] \mathrm{HSO}_{4}$ ionic liquid, and hydrolysis under microwave activation was reported. ${ }^{21}$ However the biocompatibility of these sulfonate derivatives towards hemicellulolytic enzymes and microorganisms could be questionable in regard of the cysteine content in proteins. ${ }^{22}$

In the present work, we synthesized a new family of ZILs derived from the renewable natural amino acid L-histidine by varying the length of the alkyl chains. This new ZIL family was then described in term of structural and physicochemical properties before interaction studies with membranes of microorganisms. This approach will give supplementary information for the development of lignocellulosic biorefinery. Cytotoxicity study of the ZILs was then carried out with representative micro-organisms: bacteria (unicellular, prokaryotic), yeasts (unicellular eukaryotic) and molds (pluricellular eukaryotic). A molecular modelling study was also undertaken to provide comprehensive information about ZILs and biological membrane interactions and explain the biocompatibility of ZILs with cells. The potential of ZILs for LCB pretreatment prior to enzymatic saccharification was then investigated and compared to the performances obtained with $\left[\mathrm{C}_{2} \mathrm{mim}\right][\mathrm{OAc}]$. For this, two distinct representative LCB were selected: forest residues (oak sawdust) and dedicated crop (Miscanthus $x$ giganteus). Finally, the biocompatibility of ZILs with the fermentative reference yeast, $S$. cerevisiae, was evaluated.

\section{Results and discussion}

\section{Biobased-ZILs synthesis}

ZIL derivatives have been synthesized following the general Scheme 1 starting from the known intermediate $\mathbf{A}$, easily obtained in two steps from the commercially available biobased urocanic acid (resulting from enzymatic deamination of natural L-histidine amino acid). ${ }^{23}$

First, the iodide derivatives 1-5 were obtained by $\mathrm{N}$-alkylation reaction, with yields ranging from $94 \%$ to $99 \%$, by stirring 2.1 to 3 equivalents of the corresponding alkyl iodide with $\mathrm{K}_{2} \mathrm{CO}_{3}$ in acetone under reflux for $1 \mathrm{~h}$ to 3 days with the ester derivative $\mathbf{A}$. In presence of a strong basic resin such as Amberlite IRN78, the ZIL1 to ZIL5 were obtained with yields ranging from $85 \%$ to $99 \%$. In addition to these excellent yields, no chromatographic purification was necessary to obtain purified ZILs. A detailed experimental procedure is reported in the supporting information together with the full characterization of each product.

\section{Biobased-ZILs properties}

Taking into consideration the melting point as one of the criteria for being considered as IL, only ZIL1 cannot be considered as IL since its melting point is higher than $100{ }^{\circ} \mathrm{C}(+$ $\left.109^{\circ} \mathrm{C}\right)$.
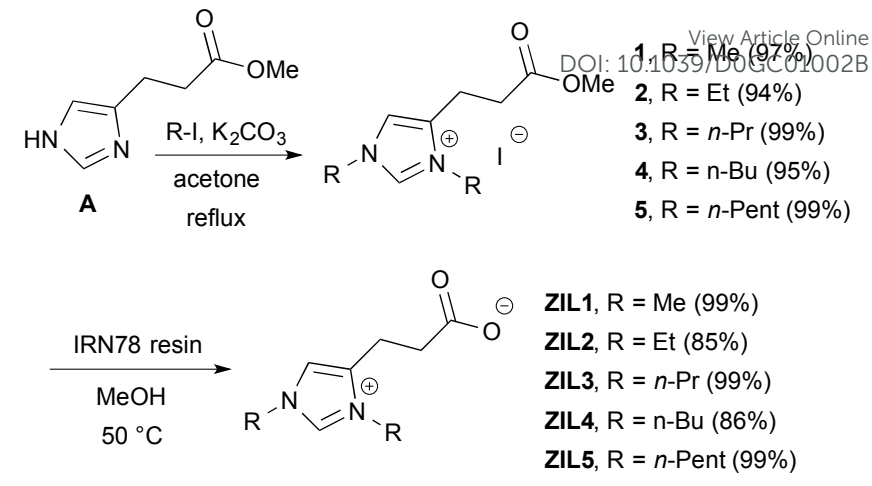

Scheme 1. Biobased-ZILs synthesis.

All the ZIL derivatives possess a glass transition temperature (Tg) from $-5{ }^{\circ} \mathrm{C}$ to $-36{ }^{\circ} \mathrm{C}$ which increased in the opposite way to the length of the substituted alkyl chain, as already described by Biswas et al. ${ }^{16}$ Data are summarized in Table 1 and compared to $\left[\mathrm{C}_{2} \mathrm{mim}\right][\mathrm{OAc}]$, the IL mainly reported and used for the LCB pretreatment as a compromise between efficiency and toxicity. ${ }^{24-26}$

Thermogravimetric analysis (TGA) under argon atmosphere (Figure 1) of all ZIL derivatives were performed. The obtained thermograms showed a first mass loss at around $100{ }^{\circ} \mathrm{C}$ corresponding to the water content (values indicated in Table 1) reaching a value close to $16 \%$ for ZIL1 showing the hygroscopic behavior of this compound. All biobased ZILs showed thermal stabilities limits of $250{ }^{\circ} \mathrm{C}$ to $315^{\circ} \mathrm{C}$, with little effect of the chain length in contradiction with the work reported by Dinda et al. in $2008 .{ }^{27}$

These values are very close to the temperature of degradation of 1-ethyl-3-methylimidazolium acetate [ $\left.\mathrm{C}_{2} \mathrm{mim}\right][\mathrm{OAc}]$.

Table 1. Characterization data of the synthetized biobased-ZILsand commercially available $\left[\mathrm{C}_{2} \mathrm{mim}\right][\mathrm{OAc}]$

\begin{tabular}{ccccc}
\hline Compound & $\mathrm{T}_{\mathrm{g}}\left({ }^{\circ} \mathrm{C}\right)^{\mathrm{a}}$ & $\mathrm{T}_{\mathrm{m}}\left({ }^{\circ} \mathrm{C}\right)^{\mathrm{a}}$ & $\mathrm{DTG}\left({ }^{\circ} \mathrm{C}\right)^{\mathrm{b}}$ & $\begin{array}{c}\text { water } \\
\text { content }(\%)^{\mathrm{b}}\end{array}$ \\
\hline ZIL1 & -5 & +109 & +255 & 15.8 \\
ZIL2 & -23 & +97 & +264 & 7.8 \\
ZIL3 & -30 & - & +276 & 11.0 \\
ZIL4 & -35 & +64 & +280 & 9.5 \\
ZIL5 & -36 & - & +314 & 5.9 \\
{$\left[C_{2}\right.$ mim][OAc] } & - & - & +245 & 0.3
\end{tabular}

aDetermined using DSC under argon atmosphere from 25 to $-60{ }^{\circ} \mathrm{C}$ then to $200{ }^{\circ} \mathrm{C}$. b ${ }^{b}$ Determined using thermogravimetric analysis under argon atmosphere from 50 to $800^{\circ} \mathrm{C}$. 


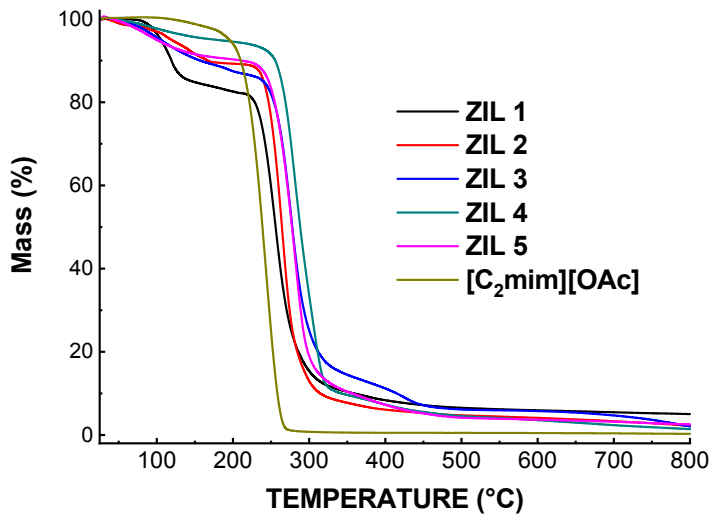

Figure 1. TGA of synthetized biobased-ZILs and commercially available $\left[\mathrm{C}_{2} \mathrm{mim}\right][\mathrm{OAc}]$ under argon atmosphere from 50 to $800^{\circ} \mathrm{C}$.

\section{Biobased-ZILs cytotoxicity}

In order to test the toxicity of the ZIL derivatives, we investigated the minimum inhibitory concentration (MIC) of the five ZILs on several microorganism species: (i) two bacteria, the Gram-negative Escherichia coli and the Gram-positive Staphylococcus aureus, (ii) two yeasts, the model ethanologenic Saccharomyces cerevisiae and the pentosefermenting Scheffersomyces stipitis (formerly Pichia stipitis), and (iii) two common molds, Aspergillus brasiliensis (formerly Aspergillus niger) and Penicillium chrysogenum (Table 2). The versatile $\left[\mathrm{C}_{2}\right.$ mim] $[\mathrm{OAc}] \mathrm{IL}$ was taken as a reference. ${ }^{8}$

Firstly, the five ZIL derivatives induced different MIC values depending on the length of the alkyl chains. The most biocompatible ZIL was ZIL2 (ethyl chain) which showed the highest MIC values with all the strains tested, from 200 to 400 $\mu \mathrm{g} / \mathrm{mL}$ depending on the microorganisms: molds were the most tolerant to ZIL2 (MIC $300-400 \mu \mathrm{g} / \mathrm{mL}$ ) compared to bacteria and yeasts (MIC 200-250 $\mathrm{gg} / \mathrm{mL}$ ). ZIL1 exhibited a biocompatibility very close to ZIL2 and the MIC values were identical for both molecules for E. coli, S. aureus and $S$. cerevisiae; they were slightly lower for S. stipitis, A. brasiliensis and $P$. chrysogenum. When increasing the ZIL chain length (ZIL3 to ZIL5), MIC values decreased gradually indicating a greater toxicity. Bacteria, yeasts and molds were equally sensitive to ZIL5 with a MIC value equal to $50 \mu \mathrm{g} / \mathrm{mL}$ for all the microorganisms except for $P$. chrysogenum which showed a MIC of $100 \mu \mathrm{g} / \mathrm{mL}$.

Secondly, the ZIL biocompatibility was much higher than the classical $\left[\mathrm{C}_{2} \mathrm{mim}\right][\mathrm{OAc}] \mathrm{IL}$ for all the ZIL derivatives on all the microorganisms tested. For example on $S$. cerevisiae, the MIC values was $20 \mu \mathrm{g} / \mathrm{mL}$ for [ $\mathrm{C}_{2} \mathrm{mim}$ ][OAc], $250 \mu \mathrm{g} / \mathrm{mL}$ for ZIL2 and $50 \mu \mathrm{g} / \mathrm{mL}$ for ZIL5. The only exception observed was specifically for the ZIL5 on A. brasiliensis which showed a MIC value of $50 \mu \mathrm{g} / \mathrm{mL}$ whereas the [ $\mathrm{C}_{2}$ mim] [OAc] induced a MIC of $150 \mu \mathrm{g} / \mathrm{mL}$. Except this particular condition, all ZILs derivatives were much more biocompatible than $\left[\mathrm{C}_{2}\right.$ mim] [OAc] until 25 times for ZIL2 on S. aureus.
Table 2. MIC values in $\mu \mathrm{g} / \mathrm{mL}$ on several microorganism species.

\begin{tabular}{|c|c|c|c|c|c|c|}
\hline \multirow[t]{2}{*}{ Compound } & \multicolumn{2}{|c|}{ Bacteria } & \multicolumn{2}{|c|}{ Yeasts } & \multicolumn{2}{|c|}{ Molds } \\
\hline & $\begin{array}{l}\bar{\vdots} \\
\text { ù }\end{array}$ & 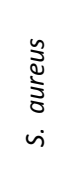 & 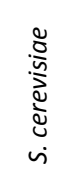 & 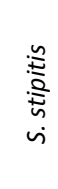 & 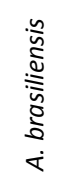 & 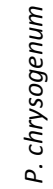 \\
\hline ZIL1 & 200 & 250 & 250 & 150 & 200 & 350 \\
\hline ZIL2 & 200 & 250 & 250 & 200 & 300 & 400 \\
\hline ZIL3 & 150 & 100 & 200 & 150 & 300 & 350 \\
\hline ZIL4 & 50 & 50 & 100 & 50 & 150 & 250 \\
\hline ZIL5 & 50 & 50 & 50 & 50 & 50 & 100 \\
\hline$\left[\mathrm{C}_{2} \mathrm{mim}\right][\mathrm{OAc}]$ & 10 & 10 & 20 & 20 & 150 & 90 \\
\hline
\end{tabular}

\section{Computational study}

ILs are frequently described as perturbators of the cytoplasmic membrane integrity in microorganisms, inducing toxicity problems. ${ }^{28-31}$

We thus used molecular simulations to study the membranotropic effects of ZILs of different alkyl chain length, compared to $\left[\mathrm{C}_{2} \mathrm{mim}\right][\mathrm{OAc}] \mathrm{IL}$. We simulated the behavior of a typical Saccharomyces cerevisiae membrane under the influence of these ionic liquids at long timescales (4.5 $\mu \mathrm{s})$ using the MARTINI coarse-grained (CG) force field, ${ }^{32}$ whose performance for the simulation of membranes has been amply demonstrated (Marrink and Tieleman 2013). Inspired by the MARTINI representations of histidine, glutamic acid and linear alkyl chains, we designed three CG ZIL models, termed CGOb to CG2b, spanning atomistic ZIL1 to ZIL5. Due to the degeneracy of the grain-to-atom mapping, each CG model represents more than one ZIL (Figure 2). [ $\mathrm{C}_{2}$ mim][OAc] was similarly constructed, on the basis of $\mathrm{CGOb}$ and $\mathrm{CG} 1 \mathrm{~b}$ but lacking the connection between beads SC4 and Qa. The models were validated by comparing structural and thermodynamic properties between matching atomistic and coarse-grained simulations.

The composition of the membrane, taken from Vermass et al., ${ }^{33}$ was chosen to mimic the experimental headgroup compositions of $S$. cerevisiae W303-1A, itself a good compromise between the compositions observed in the different $S$. cerevisiae strains. Each leaflet had a composition ratio of 30:14:12:9:4:1 of phosphatidyl choline (PC), phosphatidyl ethanolamine (PE), phosphatidyl inositol (PI), ergosterol, phosphatidyl serine (PS), and phosphatidic acid (PA) headgroups. The lipid tail composition and number of insaturations reproduced those observed by mass spectrometry and were comparable for all lipids involved: 55\% palmitoyl-oleyl class (C16:0-18:1), 22\% stearyl-linoleyl class (C18:0-C18:2), and 23\% dioleyl class (C18:1-C18:1).

We first examined the durability of the contacts established between the different ionic liquids and the yeast membrane, and whether the latter's structural integrity was retained. The different CG IL and ZIL models were found to have strikingly different effects on the membrane (Figure 3). 


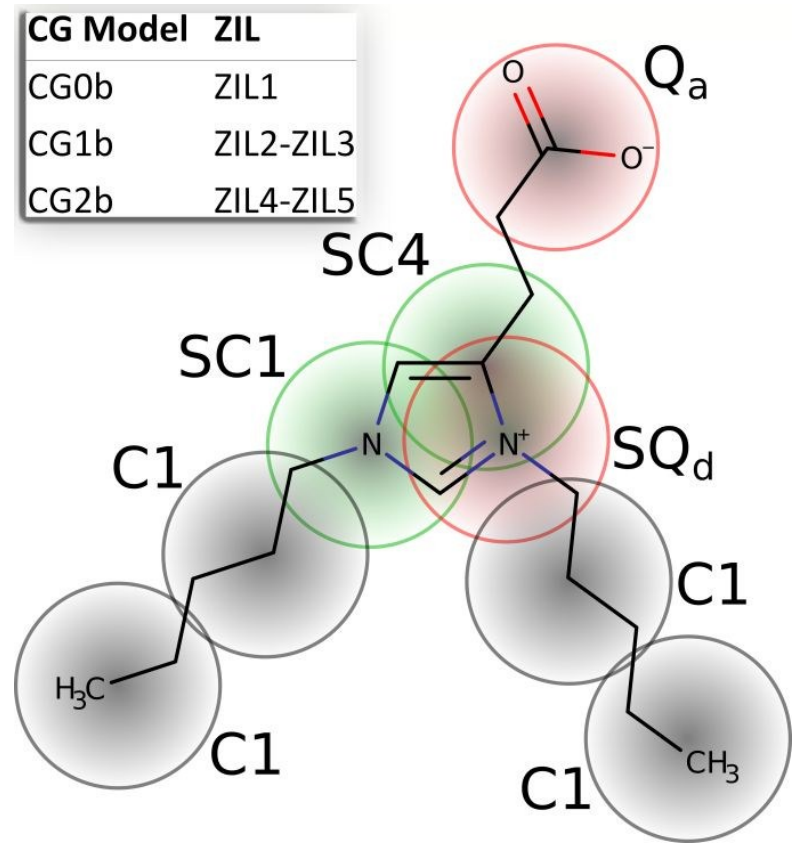

Figure 2. Left: atom-to-bead mapping of the ZILs. The beads are labelled by their MARTINI atom type and colored according to their chemical character (red green and black for charged, polar and apolar, respectively). Inset: equivalence the number of $C 1$ beads of the alkyl chains.
the

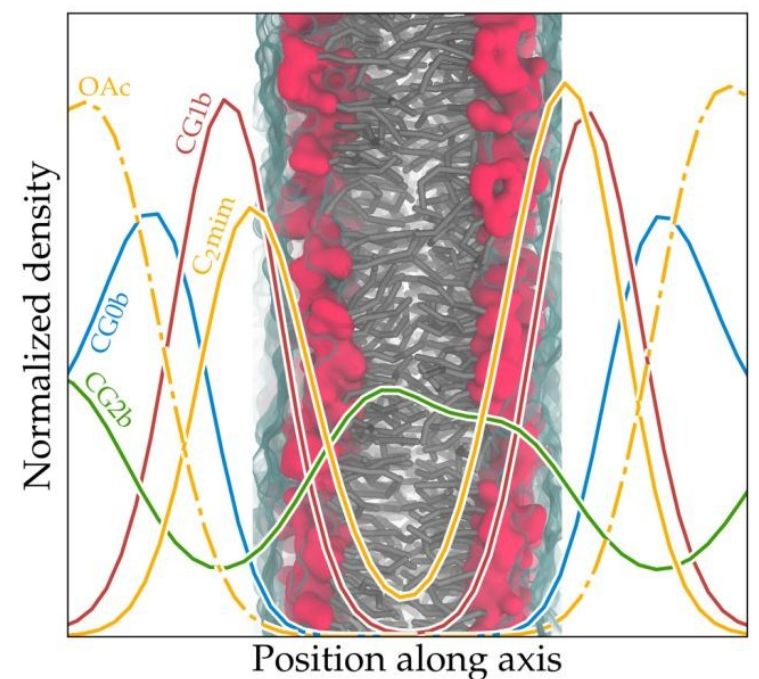

Figure 3. Normalized density of ILs along the membrane normal axis. The surface: polar heads; blue surface: first hydration layer).

ZIL1 (CGOb) had no effect: as can be seen from the position of the density peak, it tended to remain in solution and only formed transient contacts with the membrane. The density curve reveals that ZIL2-ZIL3 (CG1b) also preserved the integrity of the membrane but interacted much more durably with it, at times penetrating the polar head group layer. The cation part of $\left[\mathrm{C}_{2} \mathrm{mim}\right][\mathrm{OAc}]$ showed a similar affinity for the membrane; despite slightly more frequent occurrences of ingress inside the head group layer, it preserved the membrane's overall integrity. However, in stark contrast to ZIL2-ZIL3 where cation and anion are covalently bound, the [OAc] anion became fully dissociated and remained in solution. Finally, ZIL4-ZIL5 (CG2.b) were seen to penetrate much deeperDभito eventually splitting it into several components. The main steps of the membrane degradation mechanism are presented on Figure 4. The ZIL molecules were seen to aggregate (upper left panel), forming a wedge which was driven between individual membrane components (lower panel); the local increase in lipid density which ensued destabilized the membrane via repulsions between the dipoles of the lipid headgroups. The effect was amplified by the dipolar nature of the ZILs themselves and their similarity with the membrane components, despite shorter hydrophobic tails. This resulted in the progressive separation of membrane patches (upper right panel) and the eventual breakup of the membrane in a simulation time of under $100 \mathrm{~ns}$, which was roughly equivalent to $0.5 \mu$ s considering the typical MARTINI kinetic speedup compared to all-atom models. ${ }^{34}$

The auto-aggregative power of ZIL4-ZIL5 thus appeared crucial to their membranotropic properties. To confirm the importance of this effect, we simulated the solvated ZIL CG models in the absence of the membrane. At concentrations of $100 \mathrm{~g} / \mathrm{L}$ in water, the ZIL models showed a propensity to form transient clusters which increased with the length of the alkyl chain. This can clearly be seen on Figure 5 , where the probability of finding another ZIL molecule in close contact to a given ZIL molecule is represented as isodensity surfaces. Indeed, at longer alkyl chain lengths (CG2b), the amphiphile

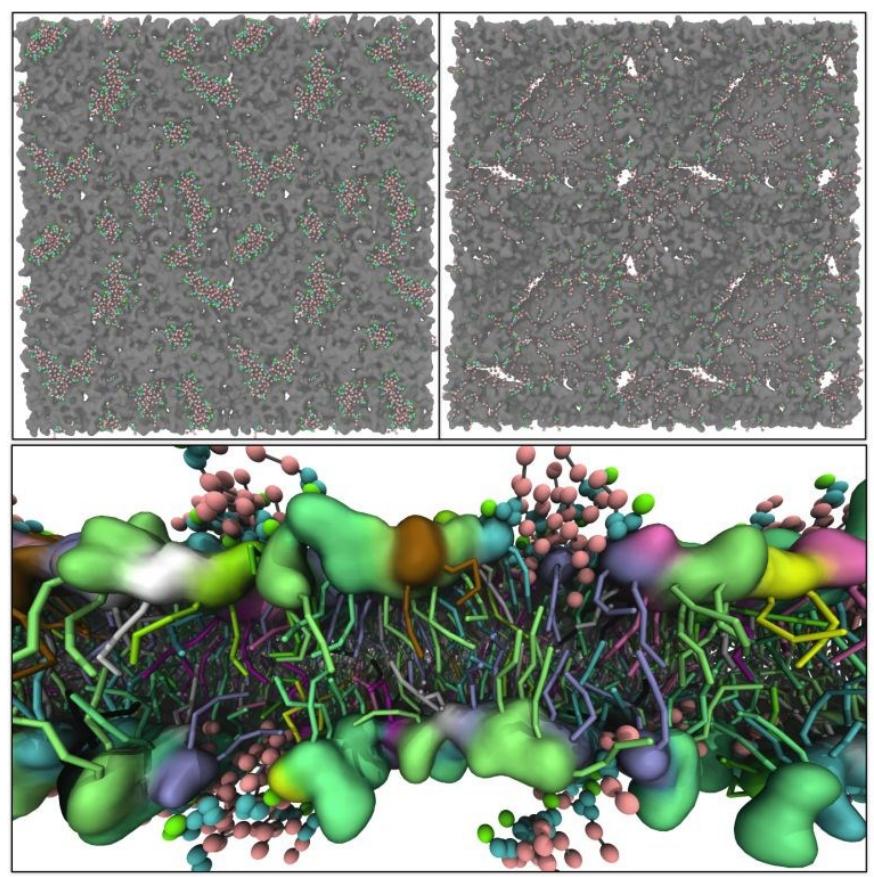

Figure 4. Top: initial events of yeast membrane breakup by the CG2b ZIL model, looking down on the membrane (gray surface). Snapshots at 10 ns into the simulation (top left), showing the clustering of the ZlLs, and 20 ns (top right), showing the onset of membrane splitting. Bottom: insertion of ZIL alkyl chains between membrane components, seen from the side (lipids colored by type; surface=polar heads; rods=hydrophobic tails). In all panels, ZIL beads are colore 


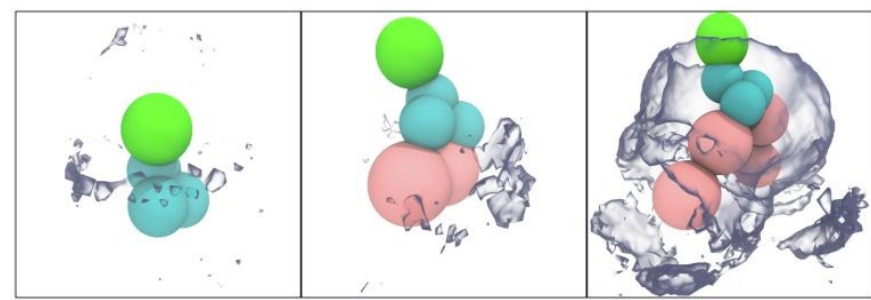

Figure 5. 70 th-percentile isodensity surfaces of ZIL molecules around a ZIL

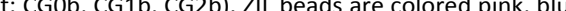
and green for the alkyl, cyclic and acid parts, respectively.

and detergent-like character of ZILs becomes sufficient to trigger self-assembly, as observed in the case of lipids. The affinity of the ZILs for themselves thus appears to be the main drive behind the breaking up of membranes by ZIL clusters. This corroborates experimental evidence that IL toxicity increases with chain length due to membrane penetration. ${ }^{28,}$ $29,35,36$

We then compared the effects of [ $\left.\mathrm{C}_{2} \mathrm{mim}\right][\mathrm{OAc}]$ and $\mathrm{CG} 1 \mathrm{~b}$ on the yeast membrane in more detail. As explained above, both exhibited similar affinities for the membrane and neither triggered a membrane breakup within the timescales under consideration. This is in agreement with several experimental studies which reported no significant effect on model membranes both for 1-ethyl-3-methylimidazolium chloride $\left[\mathrm{C}_{2} \mathrm{mim}\right][\mathrm{Cl}] \mathrm{ILs}$ with tails shorter than 6 carbon atoms ${ }^{37}$ and for $\left[\mathrm{C}_{2}\right.$ mim] $[\mathrm{OAc}] .^{38}$ However, looking more closely at the timeresolved dynamics of the membranes in our simulations revealed striking differences between $\mathrm{CG} 1 \mathrm{~b}$ and $\left[\mathrm{C}_{2} \mathrm{mim}\right][\mathrm{OAc}]$. [ $\left.\mathrm{C}_{2} \mathrm{mim}\right][\mathrm{OAc}]$ had a profound influence on fundamental dynamical membrane properties such as the distribution of areas per lipids (APL, Figure 6). In the presence of this IL, the distribution of APL over the membrane surface lost its homogeneity and featured locally large APL values, hinting at the formation of transient hole defects. Conversely, CG1b had no major impact on the distribution of APL. There is mounting evidence that such transient defects in membranes could affect biological function, ${ }^{39}$ which could explain the higher toxicity of [ $\left.\mathrm{C}_{2} \mathrm{mim}\right][\mathrm{OAc}]$ compared to $\mathrm{CG} 1 \mathrm{~b}$ observed with the MIC results (Table 2). In particular, these defects could facilitate the penetration of water molecules into the membrane, which has well-known deleterious effects 40 The benefits of substituting ILs by ZILs thus DQppeapzakearfy simulation results, in good agreement with experimental evidence shown in Table 2. However, it should be kept in mind that yeasts being complex microorganisms, the toxicity of ionic liquids can have many other causes than the destabilization of cell membranes which we simulate here. In particular, the complete dissociation of the $\left[\mathrm{C}_{2} \mathrm{mim}\right][\mathrm{OAc}]$ ion pair observed in our simulations increases the positive charge at the membrane surface and could disrupt the function of membrane transporters powered by transmembrane proton gradients. Some authors have also shown that ILs could interact with the cell wall polysaccharides in yeasts and modify the cell morphology. 11, 13, 41

Other possible effects include modifications of the global cellular metabolism, ${ }^{38}$ enhancement of ethanolic fermentation yields ${ }^{11,13}$ or damage to yeast mitochondrial functions. ${ }^{42}$ Some microorganisms also possess efflux pump systems for toxic products increasing the biocompatibility of ILs. ${ }^{43}$ More research is needed to fully understand how (Z)ILs are tolerated by cells and some authors have even shown that the cytotoxicity of ILs is highly dependent on the biological system and that the same compound can be very toxic for an organism and without any effect for another. ${ }^{44}$

\section{ZIL pretreatment of lignocellulosic biomasses: enzymatic saccharification and structural properties}

Two main strategies are reported in the literature:

(i) the simultaneous strategy consisting in in situ enzymatic hydrolysis of LCB in diluted-IL aqueous media with an efficiency dependent on a compromise between a better accessibility (IL-biomass interactions) of cellulosic fraction and enzyme deactivation (IL-cellulases interactions) and, (ii) the sequential strategy defining as subsequent separated steps of IL-pretreatment of LCB then enzymatic saccharification. ${ }^{12,45,46}$ However, the ILs classically used for these approaches exhibit some drawbacks in term of toxicity, cost and recycling, thereby justifying the design of biosourced alternative nonconventional solvents.
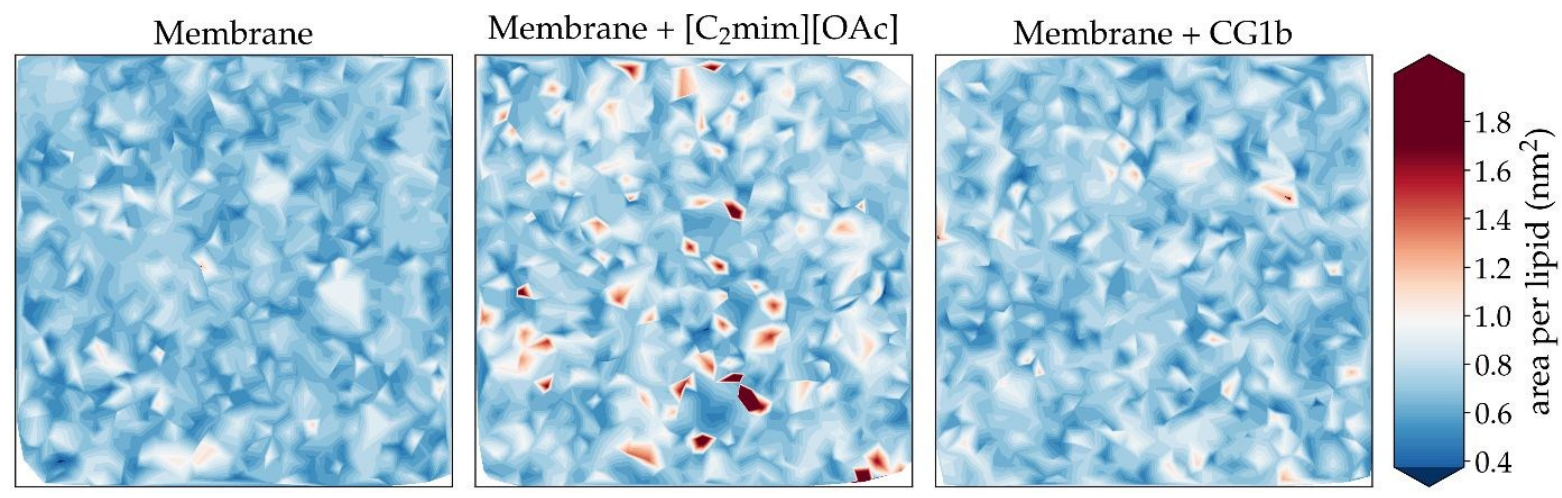

Figure 6. Top view of the membrane surface, colored by area per lipid values, for representative conformations of the membrane in the absence of IL (left), in the presence of [ $\left.\mathrm{C}_{2} \mathrm{mim}\right][\mathrm{OAc}]$ (center) or CG1b (right). 
Along these lines, the ability of carboxylate-type zwitterion ionic liquids to dissolve cellulose was reported in the literature. ${ }^{14}$ Among these new solvents, some would be suitable to improve enzymatic saccharification via a simultaneous strategy including an incubation of biomass in these solvents $\left(8 \mathrm{~h}, 120^{\circ} \mathrm{C}\right)$ before adding aqueous buffer and enzymes in one-pot. In this context, we propose for the first time to investigate the potential of our new synthesized ZILs to improve enzymatic saccharification trough a sequential strategy. Two lignocellulosic biomasses were rationally selected: Miscanthus $x$ giganteus (monocot) as dedicated crops and oak (dicot) sawdust as forestry residues. These two biomasses exhibited similar global chemical composition in term of cellulose and lignin contents.5,6 Apart from these quantitative similarities, these two biomasses are distinguished by their respective aromatic lignin content (hydroxyphenyl/guaiacyl/syringyl units ratio) and hemicellulose composition ${ }^{47,48}$ and can hence be considered as two distinct recalcitrant lignocellulosic matrices. Figure 7 presents the glucose yields obtained after saccharification catalyzed by the cellulases of $T$. reesei before (untreated) and after a short pretreatment with the different ZILs at $110^{\circ} \mathrm{C}$.

Enzymatic saccharification of both untreated biomasses led to similar yields of glucose in average of $5.74 \mathrm{~g} / 100 \mathrm{~g}$ of dried matter, confirming the recalcitrant properties of these two samples. Overall, ZIL pretreatments allowed improved the performance of saccharification regardless of the biomass. The length of $\mathrm{N}$-alkyl chains from ZIL seems to have an influence on the ability of ZIL to efficiently pretreat the biomasses prior their enzymatic saccharification. Indeed, the glucose yields increased with the increase of $\mathrm{N}$-alkyl chain length of ZIL from 1 to 2 carbons and then decreased until 5 carbons. There is an obvious correlation between the alkyl chain length on ZIL derivatives and the performances of saccharification. Indeed, Singh et al. have recently showed that imidazolium cation with lower alkyl chain length like $\left[\mathrm{C}_{2} \mathrm{mim}\right][\mathrm{OAc}]$ can interact with the aromatic rings of lignin moieties via $\pi$-stacking as well as $\mathrm{H}$-bonding. In opposite, ILs with higher alkyl chain length cannot interact as efficiently with the lignin due to steric hindrance and cause less biomass disorganization.

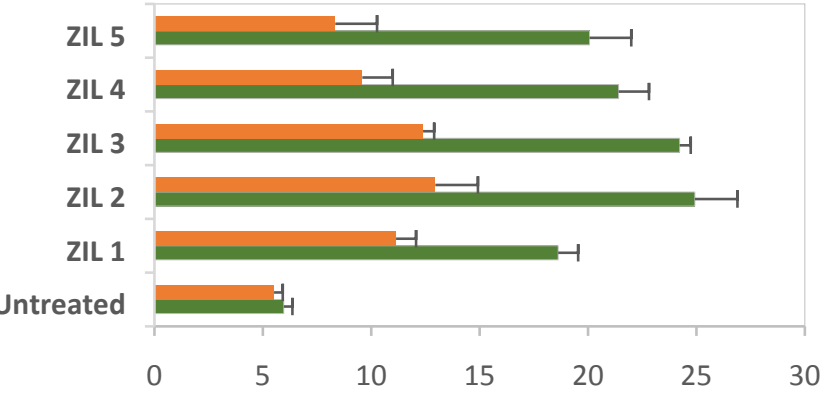

Glucose yield (g / 100g of dried matter)

Figure 7. Glucose yields (g / $100 \mathrm{~g}$ of dried matter) obtained after enzymatic (d) saccharification of Miscanthus $x$ giganteus (orange)
before and after pretreatment with the different ZILs.
The solvation of lignocellulosic polymers by ZILs duringothe pretreatment step would thus be coplstpained D by 0 sterie hindrance triggered by alkyl chains longer than 3 carbon atoms.

The improvement of saccharification appeared less marked for Miscanthus $x$ giganteus than oak sawdust with a maximal yield of glucose of $12.96 \%$ obtained after ZIL2-pretreatment versus $24.92 \%$ for oak sawdust (an increase by a factor of 4 in comparison with the untreated sample). These maximal performances obtained with ZIL2 were then compared with those obtained after $\left[\mathrm{C}_{2} \mathrm{mim}\right][\mathrm{OAc}]$ pretreatment, the reference ionic liquid for biomass pretreatment reported in the literature. ${ }^{49}, 50$ In our experimental conditions, [ $\mathrm{C}_{2}$ mim] [OAc] was shown more suitable than ZIL2 to efficiently pretreat Miscanthus $x$ giganteus prior to enzymatic saccharification with a glucose yield of $24.53 \pm 0.76 \%$. These results could be explained by SEM micrographs of Miscanthus before and after ZIL-pretreatment showing no significative disruption of the matrix, in contrast to $\left[\mathrm{C}_{2} \mathrm{mim}\right][\mathrm{OAc}]-$ pretreated sample (see supplementary data, figure $\mathrm{S} 1$ ).

On the other hand, the pretreatment of oak sawdust with [ $\left.\mathrm{C}_{2} \mathrm{mim}\right][\mathrm{OAc}]$ led to efficient saccharification (glucose yield of $27.96 \pm 1.98 \%)$, similar to that achieved after ZIL2 pretreatment. Pretreatment by ZIL2 would be thus a promising eco-alternative to $\left[\mathrm{C}_{2} \mathrm{mim}\right][\mathrm{OAc}]$ for oak sawdust pretreatment.

The structural changes induced by ZIL pretreatments were thoroughly studied in order to explain the improvement of saccharification after ZIL-pretreatment. The morphological properties of oak sawdust before and after ZIL-pretreatment were thus investigated by scanning electron microscopy (SEM) and compared to those induced by $\left[\mathrm{C}_{2} \mathrm{mim}\right][\mathrm{OAc}]$ pretreatment. Untreated oak sawdust (Figure 8A) exhibited a complex organization with a highly fibrillar morphology of strongly agglomerated particles. After ZIL-pretreatment (Figure $8 \mathrm{C}-\mathrm{G})$, the local organization of lignocellulosic matrix was altered leading to more expanded materials with individualized fibers. These modifications suggested a better accessibility of cellulosic fraction for enzymes according to the improvement of saccharification performances. Similar changes of lignocellulosic matrix were observed with $\left[\mathrm{C}_{2}\right.$ mim] $[\mathrm{OAc}]$ pretreatment (Figure $8 \mathrm{~B}$ ) as previously reported in the literature. ${ }^{6}$

Impacts on structural properties of oak sawdust were also investigated by X-ray diffraction and thermogravimetric analyses before and after ZIL2-pretreatment and then compared to those obtained after $\left[\mathrm{C}_{2} \mathrm{mim}\right][\mathrm{OAc}]$ pretreatment. The X-ray diffractogram of untreated sawdust showed a main broad peak at $22^{\circ}(2 \theta)$ and two broad humps centered at $\sim 16^{\circ}$ $(2 \theta)$ and $35^{\circ}(2 \theta)$ (Figure 9). This profile was characteristic of cellulose 1 which is a composite mixture of two distinct crystalline forms, cellulose $1 \alpha$ (triclinic) and cellulose $I \beta$ (monoclinic) in agreement with literature data. ${ }^{51}$ From these data, the crystallinity index of untreated sawdust was estimated at $51 \%$. 

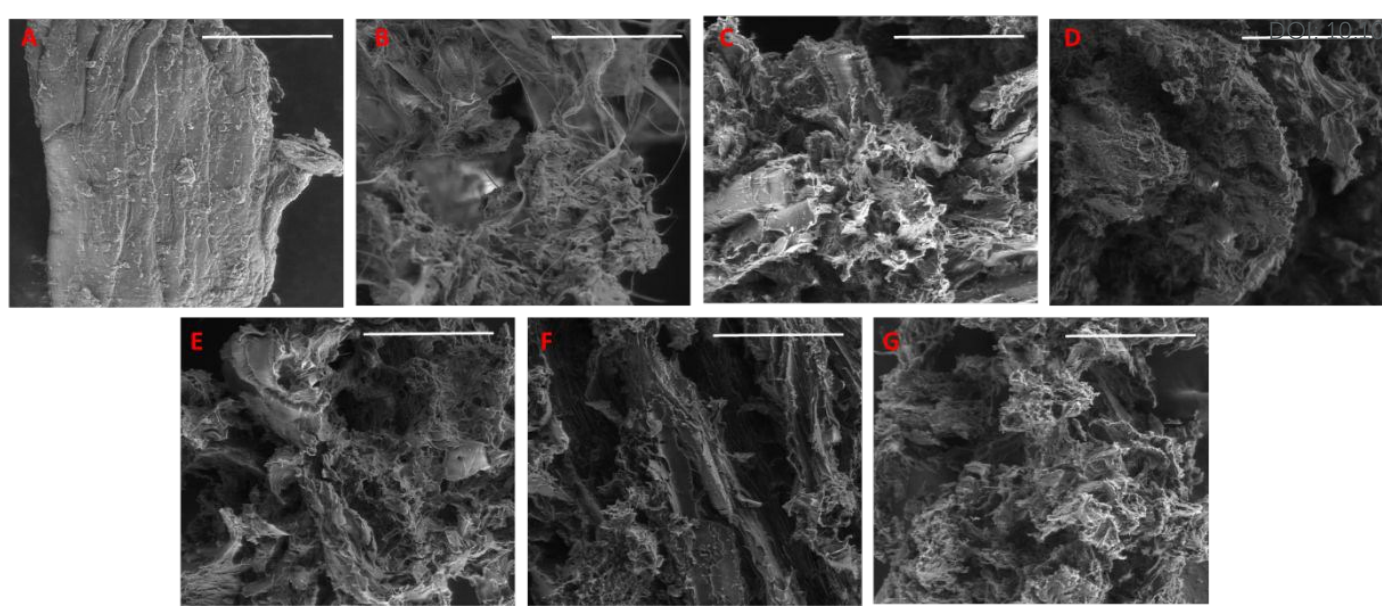

Figure 8. SEM micrographs of untreated oak sawdust (A); [ $\mathrm{C}_{2}$ mim][OAc]-pretreated oak sawdust (B); pretreated oak sawdust with ZIL1 (C); ZIL2 (D); ZIL3 (E); ZIL4 (F) and ZIL5 $(\mathrm{G})$; (scale $=50 \mu \mathrm{m}$

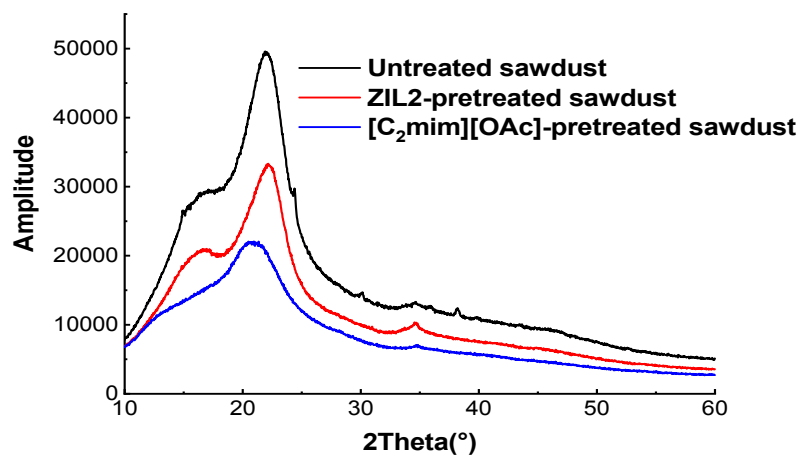

Figure 9. X-ray diffractogram of untreated oak sawdust (black), ZIL2-pretreated $110{ }^{\circ} \mathrm{C}$.

In the case of ZIL2-pretreated sawdust, the crystallinity index was $46 \%$ and no shift was observed suggesting few impacts of ZIL on the supramolecular structure of the cellulosic fraction. Conversely, $\left[\mathrm{C}_{2} \mathrm{mim}\right][\mathrm{OAc}]$ pretreatment visibly modify the crystallographic structure of oak sawdust. Indeed, [ $\left.\mathrm{C}_{2} \mathrm{mim}\right][\mathrm{OAc}]$ pretreatment resulted in the broadening of the main peak, its shift to lower angle $\left(\sim 20^{\circ}\right)$ and the disappearance of $\sim 16^{\circ}$ peak. The shift in the main peak to lower values of $2 \theta$ could indicate a transition from cellulose to cellulose II or an increase in the spacing between the stacked sheets of cellulose molecules. The decrease of $\sim 35^{\circ}$ peak intensity could be due to the partial disruption of the microfibril alignment of the cellulose chains and/or a possible depolymerization. Finally, the crystallinity index decreased from 51 to $33 \%$.

The TGA of the untreated- and pretreated-oak sawdust (Figure 10) showed a first mass loss at around $100{ }^{\circ} \mathrm{C}$ corresponding to the evaporation of absorbed bond water in the samples and, in agreement with the literature, the thermal decomposition of the sawdust between 200 and $400{ }^{\circ} \mathrm{C} .52$ Two pseudo-peaks, hemicellulose and cellulose, were present in the differential thermal analysis and their corresponding $T_{\max 1}$ and $T_{\max 2}$ are listed in the Table 3. As demonstrated by Zhang et al..$^{53}$ the increase of the $T_{\max 2}$ peak of the pretreated-oak sawdust with the ZIL2 is due to the removal of minerals which leads to an enhanced thermal stability. In the case of the $\left[\mathrm{C}_{2} \mathrm{mim}\right][\mathrm{OAc}]-$ pretreated oak sawdust sample, we observed a decrease of the $T_{\max 2}$. Indeed, XRD data showed the formation of cellulose II which involved a severe degradation of the biomass components as already mentioned by Zhang et al. ${ }^{53}$

ZIL2-pretreatment would both preserve the supramolecular structure of cellulosic biomass and avoid undesirable partial depolymerization of cellulose while improving its accessibility

Table 3. $T_{\max 1}$ and $T_{\max 2}$ peaks' position of untreated oak sawdust, ZIL2-pretreated oak sawdust and $\left[\mathrm{C}_{2} \mathrm{mim}\right][\mathrm{OAc}]$-pretreated oak sawdust for $40 \mathrm{~min}$ at $110^{\circ} \mathrm{C}$.

\begin{tabular}{cccc}
\hline Compound & $\mathrm{T}_{\max }\left({ }^{\circ} \mathrm{C}\right)^{\mathrm{a}}$ & $\mathrm{T}_{\max 2}\left({ }^{\circ} \mathrm{C}\right)^{\mathrm{a}}$ & water content $^{\mathrm{a}}$ \\
\hline Untreated oak sawdust & 293 & 344 & $5.0 \%$ \\
ZIL2-pretreated oak sawdust & 296 & 351 & $6.2 \%$ \\
$\begin{array}{c}\text { [C }{ }_{2} \text { mim] }[\mathrm{OAC}] \\
\text { pretreated oak sawdust }\end{array}$ & 281 & 339 & $3.8 \%$
\end{tabular}

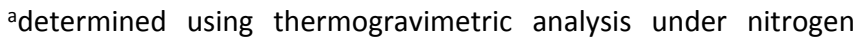
atmosphere from 50 to $800^{\circ} \mathrm{C}$.

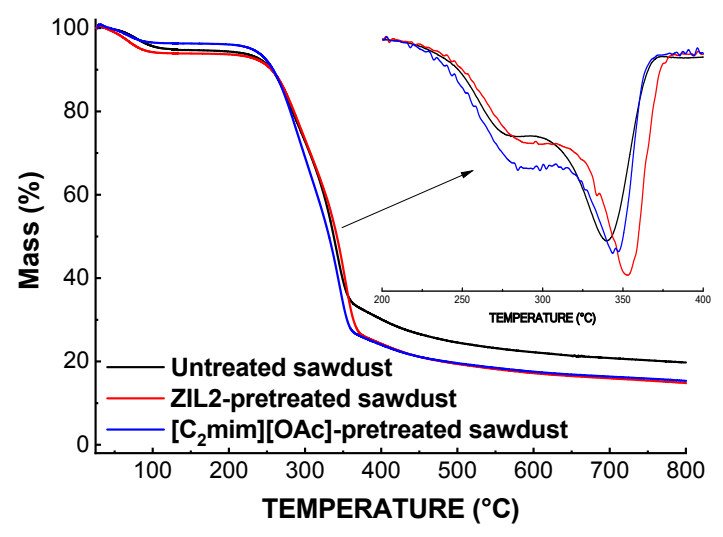
Figure 10. TGA analysis of untreated oak sawdust (black), ZIL2-pretreated oak
sawdust (red) and [ $\mathrm{C}_{2}$ mim] [OAc]-pretreated oak sawdust (blue) for 40 min at 110 sawdust (red) and [ $\left.\mathrm{C}_{2} \mathrm{mim}\right][\mathrm{OAc}]$-pretreated oak sawdust (blue) for $40 \mathrm{~min}$ at 110 ${ }^{\circ} \mathrm{C}$. 
to cellulases. ZIL2 was thus demonstrated to be more suitable than $\left[\mathrm{C}_{2} \mathrm{mim}\right][\mathrm{OAc}]$ to implement eco-friendly pretreatment in preserving structural integrity of cellulosic polymer. We suggested also that the disruption mechanism of lignocellulosic matrix induced by ZIL2 would be thus distinct than those of $\left[\mathrm{C}_{2} \mathrm{mim}\right][\mathrm{OAc}]$.

\section{Biocompatibility of ZILs at different concentration for ethanol production.}

ZIL2 was the ZIL derivatives giving the better results of enzymatic hydrolysis after LCB pretreatment. We then searched if the potentially residual quantity of ZIL2 remaining entrapped in the pretreated biomass could have a toxic effect on the downstream process such as yeast ethanolic fermentation or cellular production of any other compound of interest, as was observed with the classical $\left[\mathrm{C}_{2}\right.$ mim] [OAc] IL. ${ }^{1-3}$ Indeed, we tried to determine if low ZIL2 concentrations could influence the $S$. cerevisiae fermentation and the ethanolic production. For that purpose, we inoculated $S$. cerevisiae yeast cells in a YMD growth medium (glucose $20 \mathrm{~g} / \mathrm{L}$, yeast extract 3 $\mathrm{g} / \mathrm{L}$, malt extract $3 \mathrm{~g} / \mathrm{L}$ and peptone $3 \mathrm{~g} / \mathrm{L}, \mathrm{pH}=4.8$ ) eventually supplemented with different ZIL2 or [ $\mathrm{C}_{2}$ mim][OAc] concentrations. The growth was monitored by measurement of the Optical Density at $600 \mathrm{~nm}\left(\mathrm{OD}_{600}\right)$ (Figure 11) and the quantification of the ethanol produced by HPLC analysis (Table 4).

Table 4. Maximum ethanol yields of S. cerevisiae grown in different culture conditions.

\begin{tabular}{cc} 
Growth Medium & Maximum ethanol yields (\%) \\
\hline YMD & $84.2 \pm 1.6$ \\
YMD + $2 \%$ ZIL2 & $83.7 \pm 0.6$ \\
YMD + 5\% ZIL2 & $80.9 \pm 0.6$ \\
YMD + 10\% ZIL2 & $69.1 \pm 0.6$ \\
YMD + 0.5\% [C mim] $_{2}$ OAc] & $81.5 \pm 4.1$ \\
YMD + $\%$ [ $\mathrm{C}_{2}$ mim] $[\mathrm{OAc}]$ & N.D.
\end{tabular}

ND: No ethanol detected

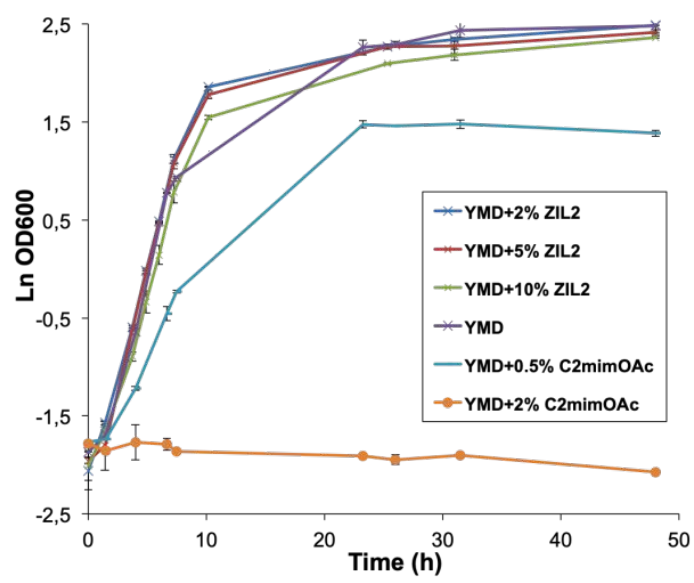

Figure 11. Growth of S. cerevisiae in YMD medium supplemented with different concentrations of ZIL2 or [ $\left.\mathrm{C}_{2} \mathrm{mim}\right]$ [OAc].
The results in Figure 11 showed that the growsth

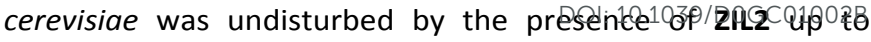
concentrations of $10 \%(\mathrm{w} / \mathrm{w})$ with exponential and stationary growth phases identical in term of duration and $\mathrm{OD}_{600}$ values, whereas the reference $\left[\mathrm{C}_{2} \mathrm{mim}\right][\mathrm{OAc}]$ induced toxicity at a concentration as low as $0.5 \%(\mathrm{w} / \mathrm{w})$ with a maximal $\mathrm{OD}_{600}$ value 3 times lower than in the YMD growth medium and no growth anymore at a concentration of $2 \%(w / w)$.

Ethanol production by $S$. cerevisiae was quantified by HPLC and the maximum ethanol yields are presented in Table 4 . In these experiments, the only ethanologenic nutrient was the glucose contained in the YMD medium. ${ }^{11}$ The highest ethanol yield was obtained when $S$. cerevisiae was grown in the YMD medium without any supplementation (84.2\%). The addition of ZIL2 at $2 \%$ had no effect on the ethanolic production (83.7\%), while at 5 and $10 \%$ a progressive decrease could be observed (80.9 and $69.1 \%$, respectively). However, when [ $\mathrm{C}_{2}$ mim] [OAc] was added to the YMD medium, the ethanol yields drastically fell from $81.5 \%$ with $0.5 \%$ [ $\left.\mathrm{C}_{2} \mathrm{mim}\right][\mathrm{OAc}]$ down to zero with $2 \%$ IL.

\section{Experimental}

\section{Chemicals, bacteria, yeasts, molds and enzymes}

All purchased materials were used without further purification. Mineral acids and bases were used in their highest concentration commercially available, from Sigma-Aldrich (Steinheim, Germany). 1-ethyl-3-methylimidazolium acetate ([ $\left.\left.\mathrm{C}_{2} \mathrm{mim}\right][\mathrm{OAc}],>98 \%\right)$ was purchased from Solvionic SA (Verniolle, France). The microorganism strains used in this study were the bacteria Escherichia coli ATCC 10536 and Staphylococcus aureus subsp. aureus CIP 53.154, the yeasts Saccharomyces cerevisiae Type II from Sigma-Aldrich (Steinheim, Germany) and Scherffersomyces stipitis CLIB 187 (formerly Pichia stipitis) from the Institut Pasteur collection, and the molds Aspergillus brasiliensis ATCC 16404 (formerly Aspergillus niger) and Penicillium chrysogenum ATCC 10106. Bacteria were cultured at $37{ }^{\circ} \mathrm{C}$ in Luria Bertani (LB) broth (peptone $10 \mathrm{~g} / \mathrm{L}$, yeast extract $5 \mathrm{~g} / \mathrm{L}, \mathrm{NaCl} 5 \mathrm{~g} / \mathrm{L}, \mathrm{pH} 7.2$ ), yeasts at $30{ }^{\circ} \mathrm{C}$ in Yeast-Malt-Dextrose (YMD) medium (glucose 20 $\mathrm{g} / \mathrm{L}$, yeast extract $3 \mathrm{~g} / \mathrm{L}$, malt extract $3 \mathrm{~g} / \mathrm{L}$, peptone $3 \mathrm{~g} / \mathrm{L}, \mathrm{pH}$ 4.8) and molds at $25{ }^{\circ} \mathrm{C}$ in RPMI- 1640 Medium with Lglutamine and without sodium bicarbonate (from SigmaAldrich) in MOPS buffer ( $\mathrm{pH} 7.0$ ).

Cellulases from Trichoderma reesei were supplied by SigmaAldrich (Steinheim, Germany) and present a specific activity of $5 \mathrm{lU} / \mathrm{mg}$; one unit liberates $1.0 \mu$ mole of glucose from cellulose in one hour at $\mathrm{pH} 5.0$ at $37^{\circ} \mathrm{C}$ ( $2 \mathrm{~h}$ of incubation).

Miscanthus $x$ giganteus was provided by UMR FARE (UMR 614 INRA URCA, Reims, France). Industrial sawdust of oak (Quercus petra) was provided by the forest industry SARL Husson Paul (Bathelémont, Lorraine, France). Raw biomasses were freezedried and then milled with planetary ball mill (Retsch PM400) during $20 \mathrm{~min}$ at $300 \mathrm{rpm}$ (particle sizes inferior to $255 \mu \mathrm{m}$ ). 


\section{Instruments}

${ }^{1} \mathrm{H}$ and ${ }^{13} \mathrm{C}$ nuclear magnetic resonance (NMR) spectra were recorded at 400 and $100 \mathrm{MHz}$ using a Bruker DRX-400 spectrometer and at 300 and $75 \mathrm{MHz}$ using a Bruker DRX-300 spectrometer. Chemical shifts are reported in parts per million relative to a residual solvent peak for $\mathrm{CDCl}_{3}\left({ }^{1} \mathrm{H}: \delta=7.26 \mathrm{ppm}\right.$, $\left.{ }^{13} \mathrm{C}: \delta=77.16 \mathrm{ppm}\right), \mathrm{DMSOd}_{6}\left({ }^{1} \mathrm{H}: \delta=2.50 \mathrm{ppm},{ }^{13} \mathrm{C}: \delta=39.52\right.$ ppm) and $\mathrm{MeODd}_{4}\left({ }^{1} \mathrm{H}: \delta=3.31 \mathrm{ppm},{ }^{13} \mathrm{C}: \delta=49.00 \mathrm{ppm}\right)$. Peak multiplicity is reported as: singlet $(\mathrm{s})$, doublet $(\mathrm{d})$, triplet $(\mathrm{t})$, multiplet $(\mathrm{m})$ and doublet of doublet (dd). High-resolution mass spectra HRMS were obtained by electrospray ionization (ESI) using a Micromass-Waters Q-TOF Ultima Global instrument. The morphology of untreated/pretreated biomass samples was investigated by scanning electron microscopy (SEM). The method consisted of observation in low vacuum mode (under partial vacuum pressure of water) without any sample preparation step. The microscope was an environmental high-resolution electron scanning microscope Quanta 200 FEG (FEI Co., USA) with a LF (Large Field) detector. The conditions of observation were the following: acceleration voltage between of $2 \mathrm{kV}$, work distance between 5 and $9 \mathrm{ppm}$ and pressure between 0.5 and 2 mbar. Infrared spectra were obtained by using a Fourier-transform infrared (FT-IR) spectrometer (IRaffinity-1S, Shimadzu) and ATR method with a germanium prism (MIRacle 10, Shimadzu). X-Ray Powder Diffraction patterns (XRPD) were acquired using a Bruker D4 Endeavor diffractometer equipped with a $\mathrm{Cu}$ anti-cathode ( $\mathrm{K} \alpha$ radiation, operating at $40 \mathrm{kV}-40 \mathrm{~mA}$ ). Patterns were collected in the $2 \theta$ range of $10-60^{\circ}$ with a step size of $0.03^{\circ}$ and using a low background silicon holder (Bruker AXS, C79298A3244B261). Crystallinity index (Crl) were calculated from the XDR diffractograms using the amorphous subtraction region method. TGA was recorded on a Netzsch STA $449 \mathrm{C}$ Jupiter thermal analyser instrument equipped with a differential analysis microbalance coupled with a QMS 403 Aëolos mass spectrometer with a stainless steel capillary and a Secondary Electron Multiplier (SEV) detector (Channeltron). The counting time for the mass spectrometer was $20 \mathrm{~ms}$ per $(\mathrm{m} / \mathrm{z}$ ) value (scanning width: $\mathrm{m} / \mathrm{z}=10-150 \mathrm{amu}$ ) with a resting time of $1 \mathrm{~s}$. All the ionic derivatives were stored at room temperature in closed vials before analysis. The samples (approximately $20 \mathrm{mg}$ of each compound) were heated in an alumina crucible under argon, by equilibrating at $25^{\circ} \mathrm{C}$, and following a ramp at $5 \mathrm{~K} / \mathrm{min}$ up to $800{ }^{\circ} \mathrm{C}$ and an isotherm under air atmosphere for 30 minutes (Flow rate: $50 \mathrm{~mL} / \mathrm{min}$ ). Melting points were carried out by differential scanning calorimetry on a DSC 204F1 supplied by NETZSCH-Gerätebau $\mathrm{GmbH}$, Germany. All tests were performed at a heating rate of $10 \mathrm{~K} \mathrm{~min}{ }^{-1}$, between -60 to $200{ }^{\circ} \mathrm{C}$ in argon atmosphere $(50 \mathrm{~mL}$ $\mathrm{min}^{-1}$ ) using about $10 \mathrm{mg}$ of sample. Liquid chromatography high performance Dionex Ultimate 3000 (Thermo scientific, Sunnyvale, CA, USA) consisting of an automatic sample changer, a pump and a detector type refractometer (RefractoMax 520), the column was a HyperRez XP Carbohydrate $\mathrm{H}+(300 \times 7.7 \mathrm{~mm})$ equipped with a pre-column, kept at $75^{\circ} \mathrm{C}$. The isocratic mode is used, with ultra-pure water as mobile phase; flow rate was $0.6 \mathrm{ml} / \mathrm{min}$. The retention time

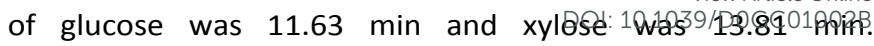
Quantification was based on calibration curves established using standard glucose and xylose.

All molecular dynamics simulations and analyses thereof were performed using GROMACS. ${ }^{54}$ All molecular graphics were generated using VMD. ${ }^{55}$ All plots were designed with Matplotlib. ${ }^{56}$

\section{Yeast fermentation}

For the yeast growth experiments and the ethanolic fermentation of $S$. cerevisiae, cultures were realized in Erlenmeyer shake flasks in YMD medium eventually supplemented with ZIL2 at $2 \%, 5 \%$ or $10 \%$, or [ $\mathrm{C}_{2} \mathrm{mim}$ ][OAc] at $0.5 \%$ or $2 \%$ (all the percentages are $w / w$ ). The inoculum was a mid-log phase preculture. The yeast growth was followed by Optical Density at $600 \mathrm{~nm}\left(\mathrm{OD}_{600}\right)$. The ethanol concentration was quantified by high performance liquid chromatography. The ethanol yields were calculated as :

$\mathrm{Y}_{\mathrm{EtOH}}=$ (concentration $_{\text {Ethanol }}(\mathrm{g} / \mathrm{L}) /$ (concentration $_{\text {Glucose }}(\mathrm{g} / \mathrm{L}) \mathrm{x}$ 0.511)) x 100

where 0.511 represents the theoretical yield of ethanol from glucose.

\section{Minimum inhibitory concentration (MIC) experiments}

For the minimum inhibitory concentration (MIC) experiments, ZIL derivatives or [ $\left.\mathrm{C}_{2} \mathrm{mim}\right][\mathrm{OAc}]$ were dissolved at $450 \mu \mathrm{g} / \mathrm{mL}$ in growth liquid media (LB for bacteria, YMD for yeasts and RPMI-1640 for molds), filter sterilized and serially diluted in sterile growth media. Each test tubes was inoculated by cell suspensions (bacteria, yeasts or mold spores) with an $\mathrm{OD}_{600}$ adjusted to 0.125 and incubated in a rotary shaker during $24 \mathrm{~h}$ for bacteria and yeasts or $72 \mathrm{~h}$ for molds under each optimal temperature conditions. The cell growth was then measured by $\mathrm{OD}_{600}$. The MIC was defined as the lowest concentration of compound which prevented the visible growth of microorganisms, ${ }^{57}$ i.e. that showed no increase in $\mathrm{OD}_{600}$. Each experiment was realized twice.

\section{[ $\left.\mathrm{C}_{2} \mathrm{mim}\right][\mathrm{OAC}]$ and ZILs pretreatments}

Lignocellulosic biomasses (LCBs) were submitted to pretreatments adapted from standard procedures reported in our previous studies. ${ }^{5,6,48} \mathrm{LCB}(2 \% \mathrm{w} / \mathrm{v})$ was added to $1 \mathrm{~mL}$ of [ $\left.\mathrm{C}_{2} \mathrm{mim}\right][\mathrm{OAc}]$ or ZILs, and incubated in an oil bath at $110^{\circ} \mathrm{C}$ with vigorous stirring for $40 \mathrm{~min}$. After incubation, the LCB was precipitated by adding ultrapure water $(2: 1 \mathrm{v} / \mathrm{v}$ water/IL) to the mixture with vigorous stirring for $30 \mathrm{~min}$ in ice bath to increase the polarity of the medium. The resulting suspension was subsequently centrifuged $(10.1733 \mathrm{~g})$ (Allegra ${ }^{\circledR}$ 64R Beckman Coulter, Indianapolis, United States) at $20^{\circ} \mathrm{C}$ for 20 $\mathrm{min}$. This step was repeated 6 times until amber-colored suspension became clear with conductivity lower than 200 $\mu \mathrm{S} / \mathrm{cm}$. This extensive washing step ensured minimization of residual [ $\mathrm{C}_{2} \mathrm{mim}$ ][OAc] or ZILs to prevent potential deleterious effect on enzymatic hydrolysis. ${ }^{8}$ The resulting insoluble 
substrate was then freeze-dried at room temperature for $24 \mathrm{~h}$ and collected for subsequent enzymatic hydrolysis.

\section{Enzymatic saccharification}

Cellulase-catalyzed hydrolysis were adapted from standard procedures described in our previous studies. ${ }^{5,} 8,48$ Freezedried untreated or pretreated LCBs were pre-incubated at $40{ }^{\circ} \mathrm{C}$ in $900 \mu \mathrm{L}$ of acetate buffer $(50 \mathrm{mM}, \mathrm{pH} 4.8)$ in Eppendorf tubes. After this pre-incubation step, reactions were started by adding cellulase mixtures from $T$. reesei. The final concentration of cellulase was $1 \mathrm{mg} / \mathrm{mL} \quad(250 \mathrm{lU} / \mathrm{g}$ of substrate). The final volume of reaction medium was $1 \mathrm{~mL}$. Reactions were carried out at $40^{\circ} \mathrm{C}$ and stirred at $1000 \mathrm{rpm}$ (Eppendorf Thermomixer 5436). After $48 \mathrm{~h}$, reactions were stopped by incubation for $20 \mathrm{~min}$ at $90{ }^{\circ} \mathrm{C}$ to deactivate enzymes. Controls with buffer/substrate and with buffer/substrate/thermally inactivated enzymes $\left(90^{\circ} \mathrm{C}\right.$, $20 \mathrm{~min}$ ) were also performed.

Supernatants of hydrolysates were recovered by centrifugation $(6000 \mathrm{~g}, 15 \mathrm{~min})$, diluted in ultra-pure water and filtered $(0.2 \mu \mathrm{m})$ prior to HPAEC analyses. Each reaction was repeated 3 times. No sugars production was detected in the absence of native enzymes.

\section{Glucose analysis}

Glucose concentrations in supernatants was determined by HPAEC using an analytical CarboPac PA-20 (150 $\times 3 \mathrm{~mm})$ column equipped with a guard column $(30 \times 3 \mathrm{~mm})$ (DIONEX, Thermo Fisher Scientific, Massachusetts, United States) and kept at $25^{\circ} \mathrm{C}$. Elution was carried out at a flow rate of 0.5 $\mathrm{mL} / \mathrm{min}$ with a gradient method using sodium hydroxide and sodium acetate as eluent, as described recently. ${ }^{8}$ The injection volume was $10 \mu \mathrm{L}$. Quantification was based on calibration curve using standard glucose solutions $(0-0.1 \mathrm{~g} / \mathrm{L})$. The retention times of glucose, $11.50 \mathrm{~min}$. The yields of the substrate conversion into glucose were expressed as mean values with standard deviations $( \pm)$ in $\mathrm{g}$ per $100 \mathrm{~g}$ of dry matter.

\section{Synthesis of ZIL derivatives}

\section{General procedure for synthesis of iodide derivatives}

To a solution of derivative $\mathbf{A}$ in acetone was added potassium carbonate ( 2 equivalents) and alkyl iodide (2.1 to 4 equivalents) and the mixture was stirred for $1 \mathrm{~h}$ to 3 days at $70^{\circ} \mathrm{C}$. After cooling at room temperature, the solvent was eliminated under vacuum and dichloromethane was added to the reaction mixture. After filtration and elimination of the solvent under vacuum, pure compounds 1-5 were obtained.

\section{General procedure for saponification}

To a solution of derivatives 1-5 in $\mathrm{MeOH}$ was added Amberlite IRN78 OH resin in a $1 / 6$ ratio. The reaction was monitored by Mass Spectrometry (MS) with Electrospray Ionization (ESI). The reaction was stopped after total disappearance of the $\mathrm{I}^{-}$anion in the reaction media with $\mathrm{MS}(\mathrm{ESI})$ in negative mode. After stirring for $30 \mathrm{~min}$ at $40^{\circ} \mathrm{C}$, the solution was filtered and the solvent was eliminated under vacuum to afford pure ZIL1-5.

\section{Computational study}

View Article Online DOI: 10.1039/DOGC01002B

\section{Parameterization of the ZIL coarse-grained models}

Atomic charges for the all-atom model of ZIL4 were obtained using the RESP approach inside Antechamber. ${ }^{58}$ Other forcefield parameters were gleaned from the GAFF forcefield. ${ }^{59}$ ZIL4 was placed in a cubic box ( 34 A per side) and solvated with 798 TIP3P water molecules. The system was minimized to convergence, heated up to $300 \mathrm{~K}$ within $100 \mathrm{ps}$ at constant volume with the ZIL4 atoms restrained $\left(500 \mathrm{~kJ} \mathrm{~mol}^{-1}\right.$ $\mathrm{nm}^{-1}$ ), then for $100 \mathrm{ps}$ at constant pressure. The restraints were progressively released over $1 \mathrm{~ns}$. The velocity-rescaling thermostat time constant was raised from $0.2 \mathrm{ps}^{-1}$ in the previous simulations to $2 \mathrm{ps}^{-1}$, and the Berendsen barostat $(0.2$ $\mathrm{ps}^{-1}$ ) was switched to Parrinello-Rahman $\left(10 \mathrm{ps}^{-1}\right)$. The system was then simulated for a $50 \mathrm{~ns}$ production run. All simulations used periodic boundary conditions, particle-mesh Ewald electrostatics, and $1 \mathrm{~nm}$ Coulomb and Van der Waals cutoffs. The time-dependent position of the atoms in the production simulation were used to obtain reference distributions of all possible bonds, angles and dihedral angles between the CG1b MARTINI beads. The parameters of the MARTINI model were adjusted so that the distributions obtained during a 50 ns coarse-grained simulation would match these reference distributions as closely as possible. This process yielded the CG1b model; the CGOb and CG2b models were generated by removing or adding a C1 MARTINI bead, with additional bond and angle parameters (in the case of CG2b) derived from the equivalent alkyl chain as already parameterized in MARTINI.

\section{Coarse-grained system setup and simulation.}

The membrane was assembled from its individual lipid components, whose topologies are available in the MARTINI 2 forcefield, ${ }^{33}$ using CHARMM-GUI. ${ }^{60}$ It was subsequently energy-minimized to convergence. Several phases of constant temperature (velocity-rescaling thermostat, $300 \mathrm{~K}, 1.0 \mathrm{ps}^{-1}$ ) and pressure (Berendsen barostat, 1 bar, $5.0 \mathrm{ps}^{-1}$ ) equilibration simulations with restrained lipid heads were successively performed: respectively 500k, 200k, 100k, 50k and 50k steps of $2 \mathrm{fs}, 5 \mathrm{fs}, 10 \mathrm{fs}, 15 \mathrm{fs}$ and $20 \mathrm{fs}$ with restraints of 200, 100, 50, 20 and $10 \mathrm{~kJ} \mathrm{~mol}^{-1} \mathrm{~nm}^{-1}$. The production simulations used a timestep of $20 \mathrm{fs}$, no restraints on any particle, a ParrinelloRahman barostat with a $12 \mathrm{ps}^{-1}$ time constant. The ZILs were introduced into the equilibrated system by randomly replacing a number of water grains, performing 100 steps of steepestdescent minimization and $200 \mathrm{k} 10-\mathrm{fs}$ steps of equilibration. The equilibrated simulation boxes had an approximate size of $20 \times 20 \times 8 \mathrm{~nm}$; their molecular compositions are given in the table below. In all simulations, the membrane, ZIL and water used separate couplings to the heat bath; similarly, the membrane normal axis was coupled to the pressure bath independently from the other two axes. The electrostatic interactions employed a reaction-field scheme (cutoff $1.1 \mathrm{~nm}$, relative dielectric constant 15 ) while the Van der Waals interactions were computed using a potential-shift Verlet scheme (cutoff $1.1 \mathrm{~nm}$ ). The simulations of the ZILs solvated in water employed similar simulation parameters, but the 
equilibration phase was reduced to $500 \mathrm{k}$ steps of $10 \mathrm{fs}$ without restraints.

\section{Conclusions}

The ZILs derivatives were obtained in few steps with excellent overall yields without chromatography purification. These new biobased ZILs have shown very high biocompatibility towards several types of microorganisms: bacteria (unicellular prokaryotic cells), yeasts (eukaryotic unicellular cells) and molds (eukaryotic pluricellular cells), ZIL2 being the best tolerated by all the microorganisms. This was confirmed by our simulations as far as membranotropic effects in yeasts are concerned which shown that ZIL2 preserved the cytoplasmic membrane integrity. Neither exchange nor dissociation can occur during the process due to the intrinsic ZIL structure, which could result in different toxicity-related mechanisms in ZIL and imidazolium-IL derivatives. The fact that the cation and anion remain on the same skeleton would be thus an advantage compared to the classical imidazolium-IL as the zwitterionic nature of ZILs suppress the hydrophobic interaction between the imidazolium $\mathrm{N}$-alkyl chains and the phospholipids. ${ }^{14}$

Finally biobased imidazolium-ZIL was demonstrated as an excellent eco-alternative to petroleum-based imidazolium ionic liquids for efficient pretreatment of hardwood prior to enzymatic saccharification

Structural and morphological properties of ZIL-pretreated LCB suggested a different molecular mechanism during the pretreatment compared to $\left[\mathrm{C}_{2} \mathrm{mim}\right][\mathrm{OAc}]$. ZIL-pretreatment preserved supra molecular structure of cellulosic fraction in LCB while increasing its accessibility and digestibility to enzymes. Moreover, low ZIL concentration had no negative effect neither on $S$. cerevisiae growth nor on ethanol production. Imidazolium based-ZILs constitutes thus promising alternative to ILs for the development of sustainable biorefinery processes.

\section{Conflicts of interest}

"There are no conflicts to declare".

\section{Acknowledgements}

ANVN thanks the ministère de l'enseignement et de la recherche for financial support. The calculations presented herein were performed using HPC resources from the MatricS computing platform of Université de Picardie - Jules Verne, Amiens, France.

\section{Notes and references}

1 K. M. Docherty and J. C. F. Kulpa, Green Chem., 2005, 7, 185189.

2 M. Ouellet, S. Datta, D. C. Dibble, P. R. Tamrakar, P. I. Benke, C. Li, S. Singh, K. L. Sale, P. D. Adams, J. D. Keasling, B. A.
Simmons, B. M. Holmes and A. Mukhopadhyay Green Chem., 2011, 13, 2743-2749. DOI: 10.1039/D0GC01002B

3 I. R. Sitepu, S. Shi, B. A. Simmons, S. W. Singer, K. BoundyMills and C. W. Simmons, FEMS Yeast Res., 2014, 14, 12861294.

4 E. Husson, S. Buchoux, C. Avondo, D. Cailleu, K. Djellab, I. Gosselin, O. Wattraint and C. Sarazin, Bioresource Technol., 2010, 102, 7335-7342.

5 T. Auxenfans, S. Buchoux, E. Husson and C. Sarazin, Biomass Bioenerg., 2014, 62, 82-92.

6 T. Auxenfans, S. Buchoux, D. Larcher, G. Husson, E. Husson and C. Sarazin, Energ. Convers. Manage., 2014, 88, 10941103.

7 E. Husson, C. Hadad, G. Huet, S. Laclef, D. Lesur, V. Lambertyn, A. Jamali, S. Gottis, C. Sarazin and A. Nguyen Van Nhien, Green Chem., 2017, 19, 4122-4131.

8 M. Araya-Farias, E. Husson, J. Saavedra-Torrico, D. Gérard, R. Roulard, I. Gosselin, H. Rakotoarivonina, V. Lambertyn, C. Rémond and C. Sarazin, Front. Chem., 2019, 7, 585-585.

9 A. Romero, A. Santos, J. Tojo and A. Rodríguez, J. Hazard. Mater., 2008, 151, 268-273.

10 T. Auxenfans, S. Buchoux, K. Djellab, C. Avondo, E. Husson and C. Sarazin, Carbohydr. Polym., 2012, 90, 805-813.

11 N. Mehmood, E. Husson, C. Jacquard, S. Wewetzer, J. Buchs, C. Sarazin and I. Gosselin, Biotechnol. Biofuels, 2015, 8, 17.

12 T. Auxenfans, E. Husson and C. Sarazin, Biochem. Eng. J., 2017, 117, 77-86.

13 N. Mehmood, R. Alayoubi, E. Husson, C. Jacquard, J. Büchs, C. Sarazin and I. Gosselin, Int. J. Mol. Sci., 2018, 19, 887.

14 K. Kuroda, H. Satria, K. Miyamura, Y. Tsuge, K. Ninomiya and K. Takahashi, J. Am. Chem. Soc., 2017, 139, 16052-16055.

15 Z. Fei, D. Zhao, T. J. Geldbach, R. Scopelliti and P. J. Dyson, Chem. - Eur. J., 2004, 10, 4886-4893.

16 Y. Biswas, P. Ghosh and T. K. Mandal, Chem. - Eur. J., 2018, 24, 13322-13335.

17 A. Ferry, K. Schaepe, P. Tegeder, C. Richter, K. M. Chepiga, B. J. Ravoo and F. Glorius, ACS Catal., 2015, 5, 5414-5420.

18 S. Mahato, R. Chatterjee, N. Chakraborty Ghosal and A. Majee, Synthetic Commun., 2017, 47, 1905-1915.

19 I. Grøssereid, K. C. Lethesh, V. Venkatraman and A. Fiksdahl, J. Mol. Liq., 2019, 292, 111353.

20 S. Suzuki, Y. Takeoka, M. Rikukawa and M. Yoshizawa-Fujita, RSC Adv., 2018, 8, 14623-14632.

21 H. Satria, K. Kuroda, T. Endo, K. Takada, K. Ninomiya and K. Takahashi, ACS Sustain. Chem. Eng., 2017, 5, 708-713.

22 S. Khademi, D. Zhang, S. M. Swanson, A. Wartenberg, K. Witte and E. F. Meyer, Acta Cryst. D, 2002, 58, 660-667.

23 R. K. Dubey, N. Kumar and R. Jain, Synthetic Commun., 2012, 42, 2207-2216.

24 D. Fu and G. Mazza, Bioresource Technol., 2011, 102, 80038010.

25 N. Sun, H. Rodríguez, M. Rahman and R. D. Rogers, Chem. Commun., 2011, 47, 1405-1421.

26 S. K. Karatzos, L. A. Edye and W. O. S. Doherty, Biotechnol. Biofuels, 2012, 5, 62-62.

27 E. Dinda, S. Si, A. Kotal and T. K. Mandal, Chem. - Eur. J., 2008, 14, 5528-5537.

28 S. P. Ventura, C. S. Marques, A. A. Rosatella, C. A. Afonso, F. Gonçalves and J. A. Coutinho, Ecotoxicol Environ Saf., 2012, 76, 162-8.

29 A. G. Santos, B. D. Ribeiro, D. S. Alviano and M. A. Z. Coelho, RSC Adv., 2014, 4, 37157-37163.

30 B. Jing, N. Lan, J. Qiu and Y Zhu, J. Phys. Chem. B, 2016, 120, 2781-2789.

31 K. Cook, K. Tarnawsky, A. J. Swinton, D. D. Yang, A. S. Senetra, G. A. Caputo, B. R. Carone, T. D. Vaden, Biomolecules, 2019, 9, 251. 
32 D. H. De Jong, G. Singh, W. F. D. Bennett, C. Arnarez, T. A. Wassenaar, L. V. Schäfer, X. Periole, D. P. Tieleman and S. J. Marrink, J. Chem. Theory Comput., 2013, 9, 687-697.

33 J. V. Vermaas, G. T. Beckham and M. F. Crowley, J. Phys. Chem. B, 2017, 121, 11311-11324.

34 S. J. Marrink and D. P. Tieleman, Chem. Soc. Rev., 2013, 42, 6801-6822.

35 T.P.T. Pham, C.-W. Cho and Y.-S. Yun, Water Res., 2010, 44, 352-372.

36 G. Quijano, A. Couvert, A. Amrane, G. Darracq, C. Couriol, P. Le Cloirec, L. Paquin and D. Carrie, Chem. Eng. J., 2011, 174, 27-32.

37 C. M. N. Mendonça, D. T. Balogh, S. C. Barbosa, T. E. Sintra, S P. M. Ventura, L. F. G. Martins, P. Morgado, E. J. M. Filipe, J. A. P. Coutinho, O. N. Oliveira and A. Barros-Timmons, Phys. Chem. Chem. Phys., 2018, 20, 29764-29777.

38 S.-K. Ruokonen, C. Sanwald, A. Robciuc, S. Hietala, A. H. Rantamäki, J. Witos, A. W. T. King, M. Lämmerhofer and S. K. Wiedmer, Chem. - Eur. J., 2018, 24, 2669-2680.

39 W. F. D. Bennett and D. P. Tieleman, Accounts Chem. Res., 2014, 47, 2244-2251.

40 R. Zappacosta, M. Semeraro, M. Baroncini, S. Silvi, M. Aschi, A. Credi and A. Fontana, Small, 2010, 6, 952-959.

41 L.-P. Liu, M.-H. Zong, R. J. Linhardt, W.-Y. Lou, N. Li, C. Huang and H. Wu, Biotechnol. Biofuels, 2016, 9, 266.

42 Q. Dickinson, S. Bottoms, L. Hinchman, S. Mcllwain, S. Li, C. L. Myers, C. Boone, J. J. Coon, A. Hebert, T. K. Sato, R. Landick and J. S. Piotrowski, Microb. Cell Fact., 2016, 15, 17.

43 C. Yu, B. A. Simmons, S. W. Singer, M. P. Thelen and J. S. VanderGheynst, Appl. Microbiol. Biotechnol., 2016, 100, 10237-10249.

44 K. S. Egorova and V. P. Ananikov, ChemSusChem., 2014, 7, 336-360.

45 S. Bose, D. W. Armstrong and J. W. Petrich, J. Phys. Chem. B, 2010, 114, 8221-8227.

46 E. Husson, T. Auxenfans, M. Herbaut, M. Baralle, V. Lambertyn, H. Rakotoarivonina, C. Rémond and C. Sarazin, Bioresource Technol., 2018, 251, 280-287.

47 J. S. Lupoi and E. A. Smith, Appl spectrosc., 2012, 66, 903 910.

48 J. Schäfer, M. Sattler, Y. Iqbal, I. Lewandowski and M. Bunzel, GCB Bioenergy, 2019, 11, 191-205.

49 A. Brandt, J. Gräsvik, J. P. Hallett and T. Welton, Green Chem., 2013, 15, 550-583.

50 L. Liang, J. Yan, Q. He, T. Luong, T. R. Pray, B. A. Simmons and N. Sun, Green Energy \& Environment, 2019, 4, 432-438.

51 G. Cheng, P. Varanasi, C. Li, H. Liu, Y. Melnichenko, B. Simmons, M. Kent and S. Singh, Biomacromolecules, 2011, 12, 933-941.

52 M. Guida and A. Hannioui, J. Mater. Environ. Sci., 2019, 10, 742-755.

53 J. Zhang, Y. Wang, L. Zhang, R. Zhang, G. Liu and G. Cheng, Bioresource Technol., 2014, 151, 402-405.

54 M. J. Abraham, T. Murtola, R. Schulz, S. Páll, J. C. Smith, B. Hess and E. Lindahl, SoftwareX, 2015, 1-2, 19-25.

55 W. Humphrey, A. Dalke and K. Schulten, J. Mol. Graphics, 1996, 14, 33-38.

56 J. D. Hunter, Comput. Sci. Eng., 2007, 9, 90-95.

57 J. M. Andrews, J. Antimicrob. Chemoth., 2001, 48, 5-16.

58 J. Wang, W. Wang, P. A. Kollman and D. A. Case, J. Mol. Graph. Model., 2006, 25, 247-260.

59 J. Wang, R. M. Wolf, J. W. Caldwell, P. A. Kollman and D. A Case, J. Comput. Chem., 2004, 25, 1157-1174.

60 S. Jo, T. Kim, V. G. Iyer and W. Im, J. Comput. Chem., 2008, 29, 1859-1865. 
Sentence for Graphical abstract :

View Article Online DOI: 10.1039/DOGC01002B

A combination of experiments and modeling reveals the influence of alkyl chain lengths in biobased ZILs on the biocompatibility towards various microorganisms. 

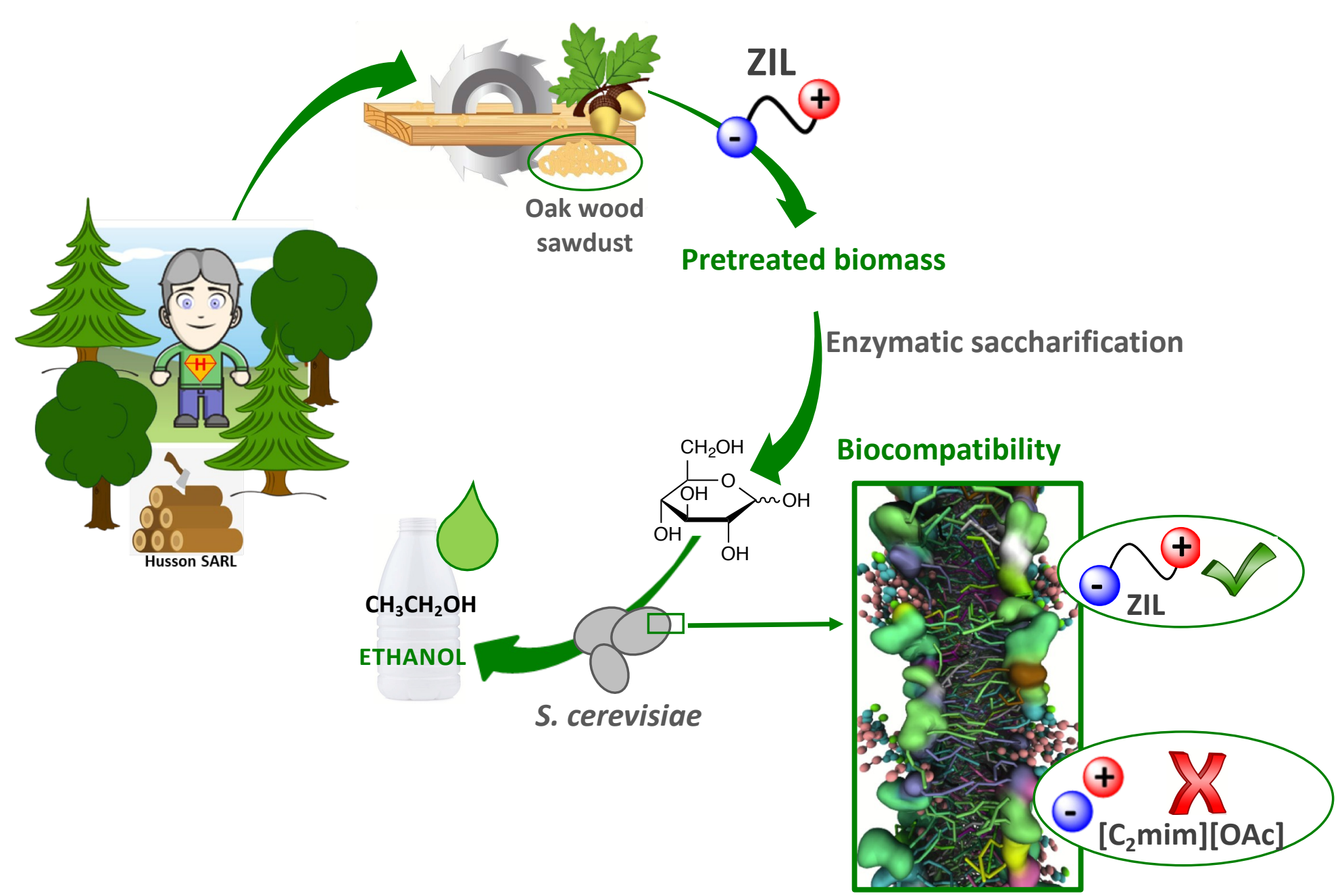

yeast membrane 